\title{
A Critical Study of Crown Gall.
}

\author{
BY \\ WILFRID ROBINSON AND H. WALKDEN.
}

With Plates V and VI and four Figures in the Text.

ROWN GALL is a widespread disease occurring on a great variety of herbaceous and woody plants in relation to wounds, particularly those produced in pruning, grafting, and in the making of cuttings. While of considerable economic importance the disease has acquired even greater interest on account of the far-reaching comparisons which have been made between it and malignant tumours in man by Dr. Erwin F. Smith, ${ }^{1}$ to whom we owe most of our knowledge of crown gall.

Toumey (34) gave the first full description of the disease, while Cavara $(2)$, Toumey, and later Hedgecock $(7,8)$ proved its infectious character by means of extensive inoculations of portions of galls into healthy plants. Erwin F. Smith and Townsend (19) first isolated the causal bacterium from the galls on the Paris Daisy (Chrysanthemum frutescens, L.) and a large number of other plants, and proved its pathogenicity by re-inoculation, naming the organism Bacterium tumefaciens, Smith and Townsend. They studied its cultural characters fully, and since that time E. F. Smith (19 to 32$)$ has carried out much experimental work on crown gall, and we are indebted to his activity for the accumulation of a vast amount of extraordinarily interesting and suggestive detail regarding the disease. $\mathrm{He}$ also early instituted comparisons between the crown gall disease of plants and malignant tumours in man; and a great deal of his experimental work has

1 Since completing our paper we have seen a recent paper by Smith on Appositional Growth in Crown-gall Tumours and in Cancers, Journ. Cancer Research, vii, 1922. In this Smith describes and figures the development of tumour-tissue by the subdivision of normal parenchyma cells. He states that a narrow strand of tumour tissue is converted into an extension of the tumour as a result of the stimulating effect of the bacteria either within the cells or acting at a distance. He now expresses the opinion that most, if not all, tumour-strands originate in this way, thus receding from his earlier position that tumour-strands and secondary galls originate by the intrusive growth or infiltration of tumour-tissue. He still maintains, however, that the tumour is due to an 'intracellular schizomycete'.

[Annals of Botany, Vol. XXXVII. No. CXLVI. April, 1923.] 


\section{Robinson and Walkden.-A Critical Study of Crown Gall.}

been carried out from this point of view. He regards most of his results as supporting the comparisons which he has drawn. It will be necessary to refer to these in some detail.

Bacterium tumefaciens is regarded by Smith as a feeble wound-parasite present in small numbers within the cells of the plants attacked, although not demonstrable by direct methods. ${ }^{1}$ The organism produces substances which stimulate the tissues to give rise to larger or smaller overgrowths according to the nature and age of the tissues affected. Along with this there is a stunting of growth and ultimately a slow killing of the plant attacked. The main comparisons with cancer and other malignant tumours have been drawn from the experimental production of secondary tumours and of 'teratomas', or crown galls bearing leafy shoots having no relation to preformed buds. The secondary tumours are described as 'growths from tumour-strands bedded deep in normal tissues derived by growth (celldivision), in the form of a continuous chain of cells, from the primary tumour'.2 Smith's photographs usually show secondary tumours at some considerable distance from the point of inoculation, and he infers that the proliferating tumour-strands have grown intrusively from the point of inoculation to the positions where secondary tumours appear.

In further support of the supposed similarity with malignant tumours he holds that 'secondary tumours reproduce the structure of the tissues in which the primary tumour has developed even when they appear in other organs; thus if the primary growth is in the stem and the secondary growth is in the leaf, the attacked part of the leaf will be converted into a pseudostem '. ${ }^{3}$ This, and the origin and nature of the secondary galls and tumour-strands, obviously require further investigation before E. F. Smith's interpretations of these aspects of crown gall can be accepted.

The need for re-investigation of these and other comparative aspects of the tumour formation in crown gall was discussed in a paper by Professor W. H. Lang (12) at the meeting of the British Medical Association in Glasgow in July, I922. We are in complete agreement with Professor Lang's general formulation of these problems, which, as he states, was made in the knowledge and light of this work then in progress. We gratefully acknowledge our indebtedness to Professor Lang for his continual interest and helpful criticism during the course of the work.

The work of some other investigators on crown gall may be briefly referred to before the scope of the present paper is indicated. Jensen (9, 10) has made observations on crown galls produced on beet by inoculation with B. tumefaciens and has compared these galls with malignant tumours.

1 In earlier papers Smith figured the bacteria in small numbers in the cytoplasm of the tumour cells. More recently he has stated that the bodies he previously demonstrated by staining with gold chloride are not bacteria.

${ }^{2}$ Smith (31), p. 4I 7 .

${ }^{3}$ loc. cit., p. $4 \mathrm{I} 7$. 


\section{Robinson and Walkden.-A Critical Study of Crown Gall. 30 I}

According to his view the presence of the bacteria, in the initial stages of the disease, provides the stimulus, which is then continued by the stimulated but uninfected cells behaving as parasitic cells similar to cancer cells. $\mathrm{He}$ has also studied another tumour growth on beet, from which it is not clear Bacterium tumefaciens can be isolated, and has successfully transferred this tumour between red and yellow forms of Beta, but there is little indication of any true infiltration of tumour-tissues in this case.

Kuster (11) states that in secondary galls caused by $B$. tumefaciens conclusive proof of the infiltration of tumour-tissues described by Smith has not been obtained, and suggests that it is more likely the effects are produced by the movement of the gall-producing organisms through the tissues of the host plant. He also denies that the stem-like structure of leaf-galls is derived by the growth of tissues from the stem into the leaf and mentions that such structure is frequently seen in other galls.

Peklo (17) produced tumour-strands and secondary galls similar to those described by Smith by the inoculation of the developing capitula of Helianthus.

Friedemann and Magnus (3) have emphasized the fact that crown galls are special irregular developments of wound tissue resulting from the infection by $B$. tumefaciens, and they hold that Smith's figures are not decisive regarding the intrusive growth of tumour-tissue. These two authors, on the grounds of cultural and serological characters, at first thought that certain strains of bacteria isolated from intestinal and some other diseases of man were identical with $B$. tumefaciens. Of the many strains so isolated only one proved capable of producing crown galls on plants. Friedemann (5), however, showed later that this organism was invariably in symbiosis with $B$. proteus, and, since it was only isolated from faeces and not from diseased tissues, that there is no real ground for ascribing to $B$. tumefaciens any pathogenicity to man.

Magnus (16), in a later paper, showed that there is no evidence in favour of the opinion expressed by Blumenthal and Hirschfield (1) that the pathogenic properties of $B$. tumefaciens can be transferred to saprophytic bacteria commonly associated with it.

Riker (18), in a paper which, so far as we know, has not been published in full, states that $B$. tumefaciens can live in soil for at least a year, and that he has obtained microscopic evidence, derived from primary and secondary galls on the raspberry, indicating that the bacteria live in small quantities in the intercellular spaces of the host. $\mathrm{He}$ also states that under certain conditions he found the organism able to travel through the vascular bundles.

Levine $(13,14$, and 15) has studied the origin of leafy growths on Bryophyllum inoculated with $B$. tumefaciens, the behaviour of crown gall on Ficus elastica, and the effect of the previous health of beetroot upon the 
reaction of this plant to crown gall. These aspects of the disease lie outside the scope of this paper.

The present work has been concerned with crown gall on Chrysanthemum frutescens and on Nicotiana affinis. Bacterium tumefaciens was independently isolated in this country in 1920 by Walkden (35) from naturally-occurring galls on Chrysanthemum frutescens. The cultural characters of the organism were fully studied by him, and it was proved by re-inoculation to be capable of causing the disease. Pure cultures so obtained by repeated re-isolations have been used for our experimental study of the disease (P1. V, Fig. 6).

In the case of Chrysanthemum frutescens the development of the galls on the cut surfaces of stems has been studied from the time of inoculation until the galls attain a large size, a strict comparison having been made at every stage with corresponding cut surfaces of uninoculated control stems. This study provided abundant material for an examination of the location of the bacteria causing the diseased growths, and we have obtained new and conclusive evidence regarding this very important matter.

We have critically repeated Smith's work on secondary tumours and tumour-strands both on Chrysanthemum frutescens and on Nicotiana affinis, and we have obtained galls similar in all respects and similarly distributed to the primary and secondary galls figured by Smith. Experimental evidence, supporting entirely different explanations from those given by Smith of the origin of these secondary galls and tumour-strands, is given below.

Although we have produced, by artificial inoculation both of Chrysanthemum and tobacco, structures precisely similar to the so-called teratomas figured and described by Smith, we do not propose to deal with these in this paper. The interpretation which we place on these so-called teratomas will, however, be briefly referred to in the discussion following the description of our other results.

It will be convenient first to describe the development of artificially produced primary galls on the Chrysanthemum from the earliest stages, then to deal with the distribution of the bacteria in the gall, and finally to describe experiments relating to the origin of secondary tumours and tumourstrands both in Chrysanthemum frutescens and in Nicotiana affinis.

\section{Development of Galls on Cut Surfaces of Shoots of CHR YSANTHEMUM FRUTESCENS.}

The material for the study of the development of galls after the inoculation of cut surfaces of stems was derived from healthy, well-grown plants of Chrysanthemum frutescens raised from cuttings and grown in 
a temperate greenhouse. For inoculation and as controls we used shoots as nearly as possible similar and equivalent. Where the lower end of a shoot was employed, this was severed from the plant by a clean transverse cut across the middle of an internode, and then, either with or without inoculation, the shoot was planted as a cutting in moist soil or sand. In other cases the apices of vigorous shoots were removed by transverse cuts through a definite internode as near as possible to the apex, and the surfaces so produced were either inoculated or left as controls, the plants being subsequently grown under ordinary greenhouse conditions.

It was found to be immaterial whether the equivalent shoots used as controls were on the same plants as those inoculated or on different plants of the same age, since precisely similar results were obtained in either case. In most of the work, therefore, the control uninoculated surfaces were made on the plant bearing the inoculated shoots. At suitable intervals of time, usually three days in the early stages, small pieces of stem, including either the inoculated or the control surface, were fixed in weak chrom-acetic acid and embedded and microtomed. Sections were usually stained with ironalum-haematoxylin, followed by orange $G$ in clove oil, or by carbol fuchsin and orange G. In addition, for special purposes hand-sections were examined in water in the fresh condition.

\section{Normal Anatomy of the Shoot.}

Pl. V, Fig. 5 , is a transverse section of the stem in the region just below the apex, where the inoculations were usually made for the production of aerial galls. The stem is of the ordinary dicotyledonous type. There is a distinct hypodermis and a small amount of collenchyma is disposed in patches. The cortical parenchyma extends about six layers of cells deep and is limited by a definite starch sheath. Mucilage ducts develop at regular intervals in the cortex near to the starch sheath, being usually situated opposite the primary medullary rays between the larger vascular bundles of the ring. The vascular ring consists of larger bundles with smaller ones between, and even at this early stage of development the pericycle is well defined opposite the vascular bundles as fibrous cells with distinctly thickened walls of pure cellulose. At this stage these pericycle cells retain their nuclei and living contents. The phloem of the bundles is a narrower zone within the pericycle and is separated from the xylem by the thin-walled desmogen cells which later function as cambium. The xylem consists of five or six radial rows of metaxylem and protoxylem vessels with conjunctive parenchyma and xylem parenchyma in the protoxylem region. The perimedullary zone is parenchymatous, but is not very clearly differentiated from the parenchymatous pith. The medullary rays are relatively narrow, being at most only eight cells wide. 


\section{Changes in Inoculated and. Control Shoots.}

According to whether the cut surface of the shoot is in contact with the soil when the shoot is treated as a cutting, or the cut surface is left exposed to the air, minor differences in behaviour are observed. The differences
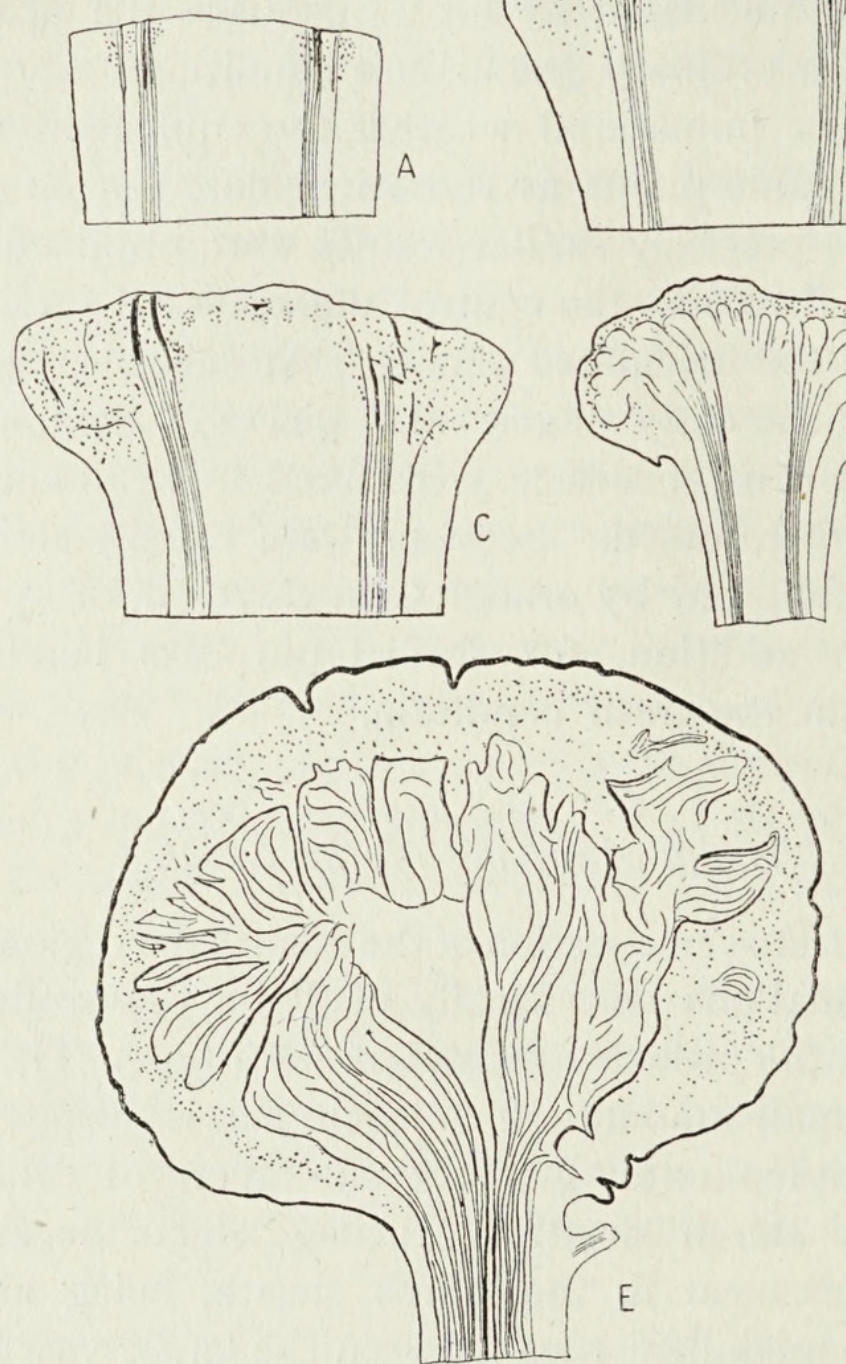

TEXT-FIG. I. Series of radial longitudinal sections through upper ends of stems at various intervals after inoculation, illustrating stages in gall formation: A after 6 days, B after 9 days, $\mathrm{C}$ after $\mathrm{I} 5$ days, D after 4 months, $\mathrm{E}$ after $5 \frac{1}{2}$ months. $\mathrm{A}, \mathrm{B}$, and $\mathrm{C} \times 9$; $\mathrm{D}$ and $\mathrm{E} \times 3$.

The dotted areas represent the position of actively dividing tissues. The blackest lines in the vascular bundles and cortex in $\mathrm{A}, \mathrm{B}$, and $\mathrm{C}$ represent positions where bacteria were observed.

are found in both the inoculated and uninoculated shoots and are partly due to differences in polarity and partly to the different conditions in the soil and in air. Text-figs. I and 2 illustrate various stages in the development of galls, which have arisen on the upper ends of stems in air and on the lower ends of cuttings in soil, respectively. The general development is similar in the two cases, but the tumour growth is more superficial in the cuttings, the severed vascular bundles being more quickly covered over by proliferating tissue than in the aerial shoots. It is noteworthy also that in 
the former case we have frequently observed, at stages from twelve to fifteen days after inoculation, the ends of gall tracheides extending to the outer surface of the gall. The uninoculated control shoots treated as cuttings develop a small amount of parenchymatous callus (Text-fig. 3),
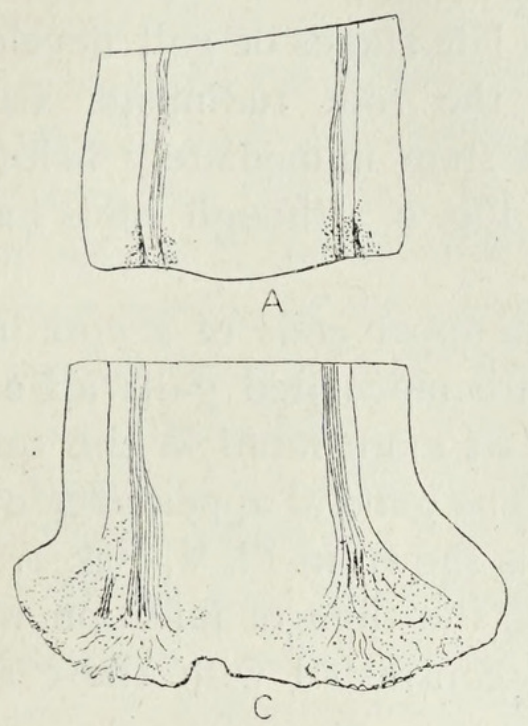
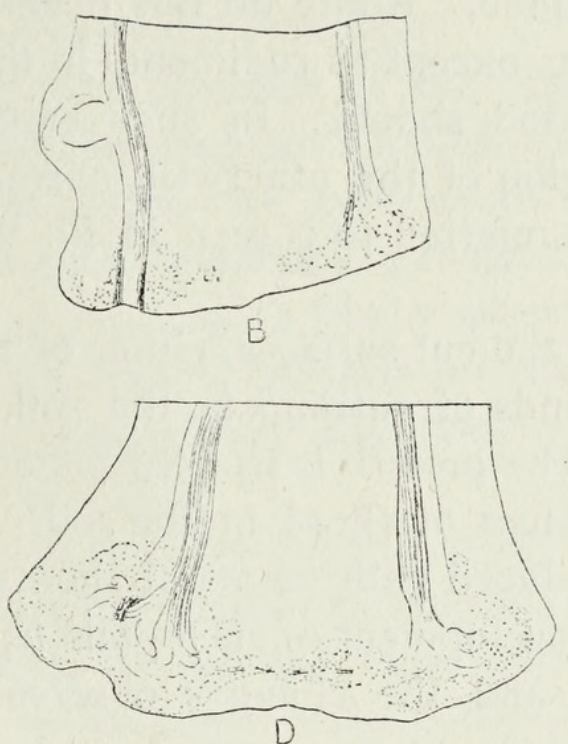

TEXT-FIG. 2. Series of radial longitudinal sections through lower ends of inoculated cuttings at intervals: A of 6 days, B of $\mathrm{I}_{2} 2$ days, $\mathrm{C}$ of $\mathrm{I}_{5}$ days, and $\mathrm{D}$ of $\mathrm{I} 8$ days after inoculation. Areas of active-tissue proliferation indicated by dotting. Regions of vascular bundles originally entered by bacteria indicated by darker lines near the ends of the former. $\times 9$.
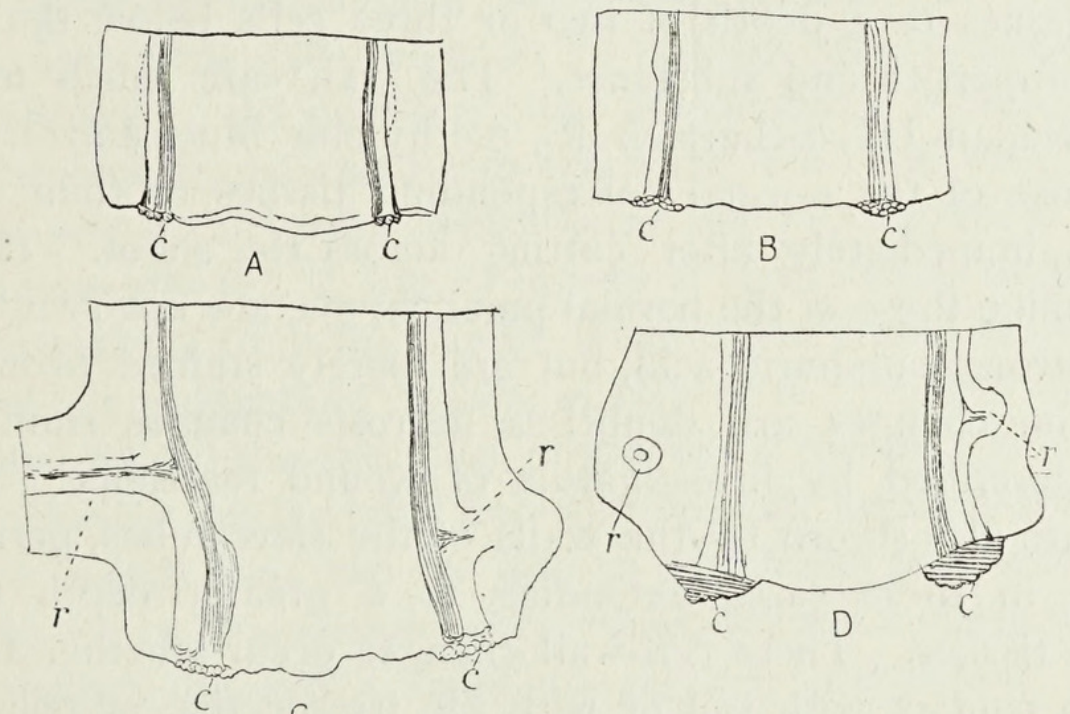

TFXT-FIG. 3. Series of radial longitudinal sections through lower ends of control, uninoculated cuttings at intervals: A of 6 days, B of 12 days, C of 18 days, and D of 2 I days after planting. The vascular bundles are indicated, and the amount of callus proliferation is shown at the ends of these bundles. $c=$ callus; $r=$ roots. $\times 9$.

whilst the cut surfaces at the upper ends of shoots exposed to air become dry and at most show a very few divisions of the cells adjoining the surface. a bulge of callus never being formed. Even in the control cuttings the amount of callus produced is never great and, so far as we have observed, is always purely parenchymatous in character, the proliferation slowing off after roots are developed behind the callus (Text-fig. 3, c). Text-fig. 3, L, 
shows the maximum amount of callus we have observed. It may be mentioned that a greater callus development occurs in cuttings of Chrysanthemum frutescens prepared through the nodal region than through the internodal region. In all our experiments the inoculations were made at an internode. Roots do not develop behind the upper cut surfaces of aerial shoots except as rudiments in the late stages of gall development on the inoculated shoots. In such cases the root rudiments arise on the swollen region of the otherwise normal stem immediately below the gall. The region referred to is seen in Pl. V, Fig. 2, although roots have not yet arisen.

When the cut surfaces, either of the upper ends of shoots in air or of the lower ends of cuttings in the soil, are inoculated galls arise and grow rapidly. The growth is usually somewhat more rapid in the case of gats in the air than of those in the soil. The general appearance of such artificially produced galls on aerial shoots is shown in Pl. V, Fig. I.

The development of such galls from the time of infection will now be dealt with and the changes observed contrasted with those seen in the controls.

Three days after wounding, the shoot (whether control or inoculated) shows marked alterations in the vicinity of the cut surface. The cells actually cut through are dead, and the walls of these, as well as the walls of all the tissues to a depth of two or three cells below the surface, are altered in properties and substance. The walls are much more readily stained by Sudan III, Scharlach R., methylene blue, and haematoxylin than are those of the normal corresponding tissues or than the walls of similar cells immediately after cutting across the shoot. These altered cell-walls, unlike those of the normal parenchyma, are not swollen and dissolved by strong sulphuric acid, but are merely stained brown with this reagent. The changes are doubtless necrosis changes similar to those previously described by investigators of wound reactions. The changes referred to are also shown by the walls of the sieve-tubes, pericycle fibres, and vessels, in these cases extending to a greater depth than in the parenchyma tissues. These cell-wall changes occur whether the wounded surface is in contact with soil or with air, irrespective of polarity, and of whether the surface is inoculated or not. In all cases, however, the maxi mum effect of the alterations described is attained in three days.

For the purposes of detailed description of the development of the gall, attention will now be confined to the galls arising on the upper ends of inoculated shoots in air. In the inoculated shoots it is evident, even after three days, that the bacteria have entered the open ends of the vessels, of the sieve-tubes, of the young pericycle fibres, and to some extent also the intercellular spaces of the cortex. The walls of the cells, with which the bacteria come into contact, show similar changes to those described above. 
Sometimes after three days, but always at six days after inoculation, the abnormal cell-divisions, leading to gall production, have commenced. The cells, particularly of the parenchyma, adjoining the regions of the vascular bundle and the cortex entered by the bacteria, show enlarged nuclei, and themselves either merely enlarge or more frequently become subdivided into smaller cells which maintain a meristematic character.

After nine days the influence of the presence of the organisms has extended laterally from the vicinity of the vascular bundles, both into the cortex and into the pith, and by this time the consequent increase in diameter of the end of the shoot is becoming evident (Text-fig. I, B). Pl. V, Fig. 7, shows a portion of the upper end of such a shoot after nine days; the dark patches seen indicate the position of bacteria on the inoculated surface, in the intercellular spaces adjoining this, and also in the vessels and in the tissues of the phloem and pericycle.

Pl. V, Fig. 9, which is a portion of a similar shoot fifteen days after inoculation, shows how the passage of the bacteria into the intercellular spaces of the cortex, some distance from the surface, may result in centres of disturbance around which gall-tissue develops by the subdivision of cells. In the Chrysanthemum, however, so far as we have observed in these inoculations, the distance the bacteria extend either along the vessels or intercellular spaces is never more than about $2 \mathrm{~mm}$., whilst in Nicotiana, as will be shown below, the bacteria may extend for a distance of some inches.

At the age of the galls shown in Pl. V, Figs. 8 and 9, while a proportion of the proliferating cells continue to be meristematic, others lose their contents and become transformed into tracheide-like cells, with characteristic reticulate or pitted thickening which later becomes lignified. In the pith these gall-tracheides (Pl. V, Fig. 8) extend at right angles to the bundle, and appear progressively from the bundle towards the centre of the pith, being formed from the products of division of pith-cells.

We must regard the effects so produced in the pith as resulting from influences diffusing out laterally from the vascular bundles, for when vertical needle-prick inoculations into the pith of cut shoots similar in age to those used for the other inoculations were made, beyond a slight subdivision or cells surrounding the needle track, no marked production of gall-tissue, including tracheides, was observed.

Later stages in the development of the gall are seen in Pl. V, Figs. 2 and 3 , and Text-fig. I, C, D, and E. The whole structure of galls in these stages is remarkably similar to the callus masses which develop on cut shoots of woody twigs (such as Populus) when kept in moist air. The gall-tissue extends completely across the pith, and the vascular bundles and cortex on either side are considerably. widened out by the gall, much of which forms irregular woody tissues with intervening parenchyma. The galls are now more or less hemispherical in shape ; there is a distinct zone of meristematic 


\section{Robinson and Walkden.-A Critical Study of Crown Gall.}

gall-cells arching over the greatly modified end of the stem; and parenchymatous cells are developed externally to this active tumour-tissue. As the gall increases in size, the outermost layers of cells of this cortical region are continually torn apart by the expansion, the layer of dead cells on the exterior becoming very marked in the older galls (P1. V, Fig. 3, C). There is, however, no production of cork on the exterior of the galls, and, as will be shown below, vast numbers of Bacterium tumefaciens are found upon the layers of dead cells on the exterior. The increase in size of the gall, in the later stages at least, seems to result from the presence of the causal bacteria in preponderant numbers in this position.

A part from the direct effect of the presence of the organisms in leading to the production of tumour-tissue there is also, as Smith's figures show, an extension backwards of the influence some distance from the actual gall. This effect is often manifested in a widening of the vascular ring by more than the ordinary cambial activity in the portion of the stem below the gall as in Pl. V, Fig. 2. A similar effect frequently may be seen in the petiole or midrib beneath a gall borne on a leaf. While dealing with our inoculations of shoots of Chrysanthemum, it may be mentioned that on several occasions we have inoculated axillary shoots growing from positions very near to galls produced by earlier inoculations. We have invariably obtained galls on such shoots, showing that there is no immunity acquired by plants against $B$. tumefaciens following an earlier infection by the crown-gall organism, as has been suggested (Pl. V, Fig. I, C).

Galls of the general type described above were repeatedly produced by inoculating the cut surfaces of the shoots of healthy plants, and these galls resembled, in every particular, the naturally occurring galls on plants grown in the nurseries. A general distinction must be drawn between the galls described above, whether naturally occurring or experimentally produced, and the secondary galls and tumour-strands to be described below. The former type of gall has a rough exterior, and develops quite differently from the latter type, which has a smooth exterior. The secondary galls and tumour-strands, described by Smith and Peklo and produced by us, are always the result of artificial inoculations and have only been met with in experiment.

The evidence which we have obtained regarding the position of the bacteria in the large galls with rough exterior on the shoots of Chrysanthemum frutescens will now be dealt with.

\section{Distribution of B. TUMEFACIENS in the Rough Galls on} CHR ISANTHEMUM FRUTESCENS.

The difficulties experienced by Walkden (35) and others in isolating B. tumefaciens from the interior of naturally occurring galls, after sterilizing 
the exterior with mercuric chloride, have been referred to by Walkden in his note on the isolation of the organism. He has pointed out that the isolation is much more readily accomplished if the external surface of the gall is not first sterilized. In isolating $B$. tumefaciens he also found that more numerous colonies of this organism are obtained when portions of the exterior of the gall are used than if the inoculum be taken from the interior of the gall after removing the surface layer. Further, when sections of living galls on aerial shoots of any age from ten days to two months or older are mounted fresh in water, we have found that the external surface of the gall invariably shows a mucilaginous film from which very large numbers of bacteria of the form, size, and general appearance of B. tumefaciens can be observed diffusing into the mounting water.

Like Smith and other investigators, we have entirely failed to demonstrate the bacteria, by staining, within the cells of the gall, nor have we obtained any evidence that the bacteria enter the living cells of the host plant. The individuals of $B$. tumefaciens present in the film of mucilaginous material on the exterior of the gall are, on the other hand, readily demonstrated by the ordinary staining methods. In the early stages of the development of galls, after the inoculation of the cut surfaces of Chrysanthemum shoots, it is possible also to demonstrate the bacteria by staining some little distance (for about $2 \mathrm{~mm}$.) along the vessels, and also occasionally in the intercellular spaces of the cortex (e. g. in Pl. V, Fig. 9, at i.s.).

The presence of the bacteria in these situations in the early stages of gall-formation is, in part at least, responsible for the shape of the gall which results from the localization of the disturbing influence in definite regions of the stem, i. e. in the vascular bundles and occasionally in loci in the cortex. It must be pointed out, however, that in the Chrysanthemum the organisms are not found at any considerable distance from the surface, and soon the form of the growing gall becomes such that the majority of the organisms producing it are localized on its surface. The further evidence for this conclusion which is indicated by the facts outlined above may now be given.

It was repeatedly found that merely dipping the unbroken gall into mercuric chloride solution ( $\mathrm{I}$ in $\mathrm{I}, \mathrm{O})$ ) for ten seconds, prior to breaking it up for making platings, was sufficient to reduce the numbers of $B$. tumefaciens found from two hundred per plate to one. This result was obtained no matter how thoroughly the gall was washed after the treatment with mercuric chloride. The suspicion therefore arose that the active organisms were situated mainly on the outer surface of the gall. To test this the following experiment was carried out :

A gall was taken direct from the plant growing under the usual greenhouse conditions, without any attempt to prevent contamination, and dropped into a tube containing Io c.c. of sterile water for ten minutes. 
The gall was then washed in running water for about four hours (thus attempting to wash off as many organisms as possible from the surface), then placed in a second tube of sterile water for ten minutes; finally the gall was cut into small pieces with a sterile scalpel, and dropped into a further io c.c. of water for ten minutes. Platings were then made, using for each plate a loopful of the water from one of the three tubes. The experiment was carried out with a number of actively growing galls from five to eight weeks old, and the results of some such tests are summarized in Table I.

\section{TABLE I.}

Platings made to test the number of Bacterium tumefaciens on the exterior and interior of galls, and also the possibility of washing galls free from B. tumefaciens.

A.

Gall placed for $10 \mathrm{~min}$. in Io c.c. sterile water.

\begin{tabular}{|c|c|c|c|}
\hline Age of gall. & $\begin{array}{l}\text { No. } \\
\text { of } \\
P l .\end{array}$ & $\begin{array}{c}\text { Total } \\
\text { bacteria. }\end{array}$ & $\begin{array}{l}\text { Bact. } \\
\text { tume- } \\
\text { faciens. }\end{array}$ \\
\hline \multirow{6}{*}{ Six weeks } & I. & 178 & 54 \\
\hline & 2. & & \\
\hline & 3. & 192 & 62 \\
\hline & 4. & & 89 \\
\hline & 5. & 164 & $5 \mathrm{I}$ \\
\hline & 6. & $\begin{array}{l}208 \\
167\end{array}$ & $\begin{array}{r}82 \\
164\end{array}$ \\
\hline \multirow{5}{*}{ Five weeks } & $\begin{array}{l}\mathrm{I} . \\
2 .\end{array}$ & $\begin{array}{r}107 \\
76\end{array}$ & $\begin{array}{r}104 \\
73\end{array}$ \\
\hline & 3. & $I_{45}$ & 142 \\
\hline & 4. & I 52 & 150 \\
\hline & 5. & 68 & 64 \\
\hline & 6. & 2 I 8 & 2 I 2 \\
\hline \multirow{2}{*}{ Eight weeks } & I. & I8o & I 55 \\
\hline & 2. & 216 & I89 \\
\hline \multirow[t]{5}{*}{ Six weeks } & I. & $\begin{array}{l}105 \\
305\end{array}$ & $\begin{array}{r}90 \\
159\end{array}$ \\
\hline & 2. & 125 & 47 \\
\hline & 3. & 207 & I 54 \\
\hline & 4. & 279 & $\mathrm{I}_{45}$ \\
\hline & 5. & $I_{47}$ & 74 \\
\hline
\end{tabular}

B.

Same gall, after washing. in running water for about 4 hours, placed in Io c.c. sterile water.

$\begin{array}{cc}\text { Total } & \text { Bact. } \\ \text { tume- }\end{array}$

30
37
32
42
32
39
98
97
98
98
94
98
86
88
85
52
37
54
52
50

C.

Same gall cut into small pieces and placed in Io $c$ c. sterile water.

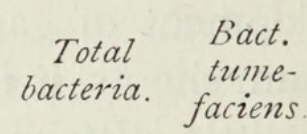

$\begin{array}{rl}9 & 5 \\ \text { I } 2 & 3 \\ 3 & 0 \\ \text { I } 5 & 8\end{array}$

It will be seen from Section A of Table I that there are enormous numbers of bacteria present on the external surfaces of the galls, and of these bacteria a large percentage is always B. tumefaciens. Section B of Table I shows that it is possible to remove most of the organisms by washing, though $B$. tumefaciens as well as other bacteria remain in small numbers. Section $\mathrm{C}$ of the table shows the small increase in the total bacteria found when the galls are cut into pieces, but there appears no justification from the figures to assume that $B$. tumefaciens is present in greater proportions than on the exterior of the unwashed gall. The num- 
bers and also the diversity of the organisms obtained from the broken galls are sufficiently accounted for by the former having lodged in crevices of the rough surface of the gall, or as the residue of the bacteria that originally penetrated some little distance below the surface of the cut shoot at the time of inoculation.

The aerobic character of $B$. tumefaciens may account for the undoubted fact that the bacteria which are introduced to the interior either of vessels or of intercellular spaces of Chrysanthemum frutescens, which has relatively small intercellular spaces, do not multiply to any extent nor grow progressively in the interior. ${ }^{1}$

Experiments, using plating methods similar to those described above, have demonstrated with certainty that, for several weeks after inoculation, there is a progressive increase in the numbers of $B$. tumefaciens present on galls left growing on the plants.

The plating experiments thus show conclusively that, in the actively growing galls with rough surface on Chrysanthemum frutescens, there are enormous numbers of bacteria situated on the exterior of the gall, that a high percentage of these is $B$. tumefaciens, and that it is reasonable to assume that the presence of these progressively increasing numbers of $B$. tumefaciens on the exterior provides the progressive stimulus which leads to the continued growth of the gall.

The facts regarding the distribution of the bacteria had obvious bearings upon the origin of the so-called secondary tumours and tumourstrands which have been so fully studied by Smith. These aspects of crown gall were therefore reinvestigated, and may now be considered.

\section{SECONDARY Tumours and Tumour-STRANDS.}

As has been stated in the introduction to this paper, we have succeeded in producing on Chrysanthemum frutescens and on Nicotiana affinis galls similar in all respects and similarly distributed to the secondary galls figured by Smith. It has not, however, been found possible, as might have been assumed from some of Smith's figures, to obtain secondary galls in Chrysanthemum frutescens at a distance from the primary inoculation by inoculating the shoot at some distance from the growing-point. With this plant we have obtained successful results only by the inoculation of the very young tissues in the vicinity of the meristematic apex. This led us to test a view suggested to us some years ago by Professor W. H. Lang, viz. that the appearance of secondary galls and of tumour-strands was due to the subsequent development, growth, and extension of the meristematic tissues under the influence of the bacteria after inoculation.

1 Below it will be seen that in the shoot of Nicotiana the bacteria behave differently in undoubtedly multiplying and progressing in the interior. 
In order to obtain as much precision as possible, the inoculations were made into a large number of shoots of similar size, age, and general vigour by means of single horizontal or vertical needle-pricks. P1. V, Fig. IO, shows the result of such a single horizontal needle-prick inoculation at the apex of a shoot of Chrysanthemum frutescens five weeks after the inoculation. Six galls of various sizes at the bases of leaves are seen in the photograph, and in addition the apex was so injured at one side that the terminal bud developed more feebly than usual, and the two nearest lateral buds pro-
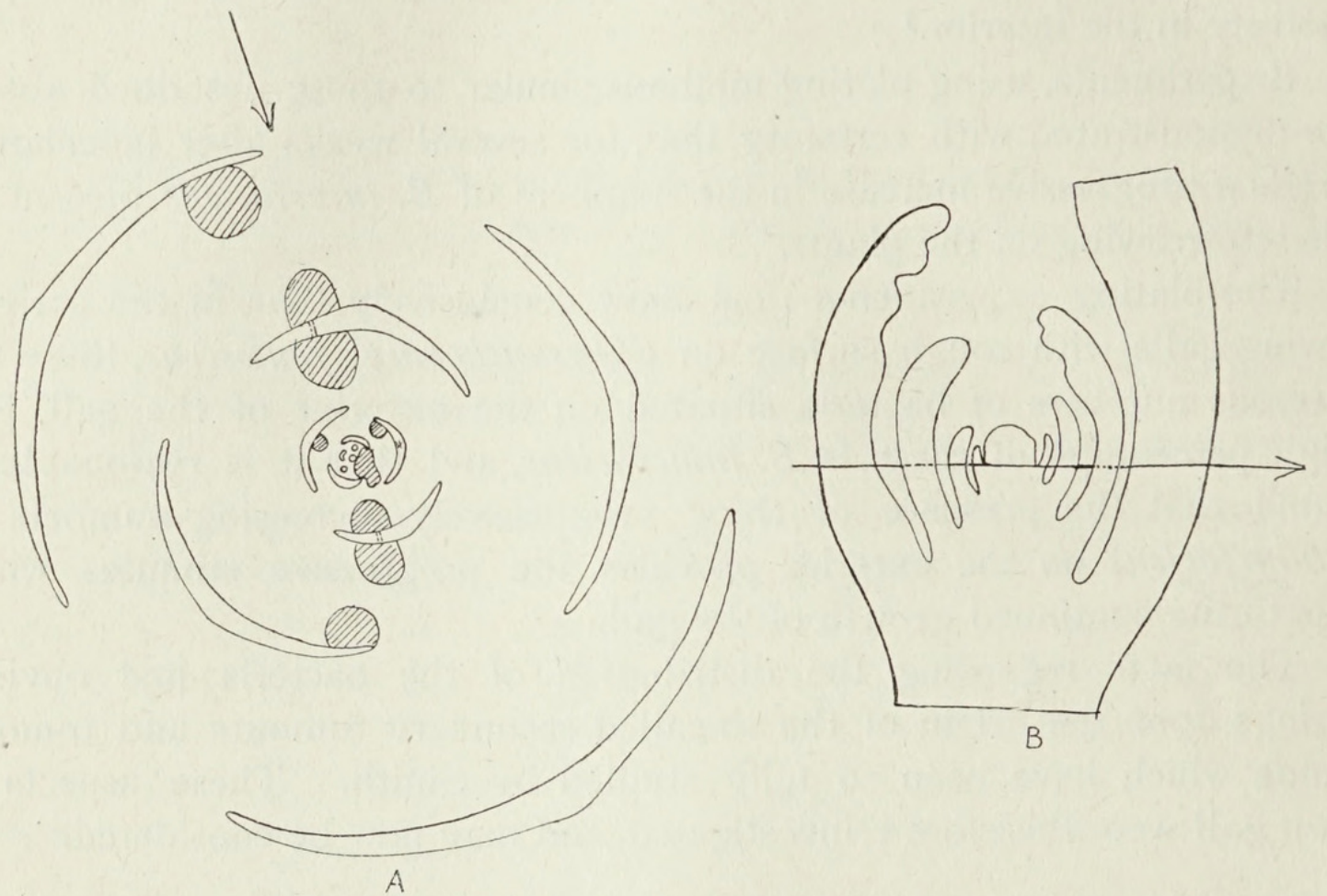

Text-Fig. 4. A. Phyllotaxy diagram of the shoot of C. Jrutescens shown in Pl. V, Fig. Io. The galls on the various leaves are indicated by the shade areas, and the arrow shows the direction taken by the needle in making the inoculation at the apex.

B. Diagrammatic representation of the presumed path of the needle shown in relation to the longitudinal view of the apical region of the same shoot.

duced shoots. The six galls, which are now widely separated from one another by one or more internodes, have arisen as a result of the inoculation of wounded rudimentary leaves at the apex of the shoot, and have been separated by the subsequent growth of the shoot. Bacterium tumefaciens is present in large numbers on the rough exterior of such galls, and can be readily isolated from them. A very slight inoculation wound is sufficient to lead to the production of such galls, and the degree of roughness of the surface visible may in such cases be very slight. Text-fig. $4, \mathrm{~A}$, is a phyllotaxy diagram of the shoot shown in Pl. V, Fig. IO, and it will be seen that the position of the galls on the various leaves is consistent with each leaf bearing a gall, having been wounded and inoculated by the single horizontal needle-prick. The arrows in Text-fig. 4, A and B, show the presumed path of the needle. A very large number of such inoculations was made, and 


\section{Robinson and Walkden.-A Critical Study of Crown Gall. $3^{1} 3$}

in most cases, but not in all, where separated galls appeared the phyllotaxy diagram indicated their connexion with the original needle-track.

In a number of other cases, however, both in longitudinal and horizontal inoculations of apices, smooth galls of a different appearance were obtained at a distance from the larger rough galls that were always directly associated with actual wounds. Such galls, which are similar to many of Smith's secondary tumours, are seen in Pl. V, Fig. I I (s.g.), and Pl. VI, Figs. I 2 ( $s . g$. $\mathrm{I}, 2$, and 3 ) and I3 (s.g.). Galls of this type only will be regarded as true secondaries. We have never found B. tumefaciens on the exterior of such smooth galls either by direct observation or by cultural methods, and, like Smith, we have had considerable difficulty in isolating the organism from the interior, but in this we were successful in two cases. We have, however, in such secondary galls directly demonstrated, by staining, the position of the bacteria in the protoxylem vessels and in the intercellular spaces adjoining these, and further we have found continuity of the organisms from such galls to the primary gall, which arises where the inoculation wound is made. The internal structure of such secondary galls may now be dealt with, and the relations of the infecting organisms to them will be made clearer after secondary galls on Nicotiana have been described.

Pl. VI, Fig. I 2, shows a portion of a shoot which was inoculated by a single longitudinal needle-prick at the apex; the rough elongated gall on the side of the shoot is a primary gall (using Smith's terminology), and extending along the midrib of the leaf are three 'secondary' galls in linear series. Pl. VI, Fig. I4, is a longitudinal section of the middle secondary gall on the leaf shown in P1. VI, Fig. I2, s.g. 2. The swelling is originating from within by the subdivision of cells of the parenchyma in a manner exactly similar to that seen in the galls on the ends of shoots dealt with in the first section of this paper. There is, in addition, a more striking subdivision and proliferation of tissues immediately adjoining the protoxylem $(p x$.) of the vascular bundle, resulting in the slight general displacement of the tissues of the parenchyma, but there is no evidence of any considerable intrusive growth of tumourtissue outwards. The elements of the protoxylem $(p x$.) stain deeply in the manner characteristic when organisms have been found in them, and the appearances generally are consistent with an influence diffusing out from the protoxylem. Pl. VI, Fig. 15, shows a transverse section of the much older elongated secondary gall (s.g.) seen in the deformed leaf in Pl. VI, Fig. I3. The structure is very similar to that frequently figured by Smith for secondary galls on the leaf of Chrysanthemum. It shows the modification of one of the vascular bundles into a radial structure, which was regarded by Smith as evidence of the stem origin of this by the intrusive growth of tumourtissue from the infected stem out to the leaf in which the secondary gall has arisen. As will be seen below, particularly clearly for Nicotiana, we have shown that such galls arise around definite centres of bacteria in the interior 
of the structures in which they appear, and we have found no evidence of any invasive growth of tumour-tissue from a distance. In the case shown in $\mathrm{Pl}$. VI, Figs. I 3 and I 5 , we have direct as well as cultural evidence of the presence of the bacteria in the protoxylem region in the centre of the modified midrib, and we have traced the organisms back along the protoxylem to the primary gall by serial microtome sections. The facts thus briefly referred to for secondary galls on Chrysanthemum frutescens were made out only after a considerable body of our work had been completed since, as has been mentioned, like Smith, we experienced great difficulty in isolating the organisms from the secondary galls on the Chrysanthemum.

Parallel studies, however, which we carried out on Nicotiana affinis enabled us successfully to stain and thus directly demonstrate the bacteria in the interior of secondary galls on this plant, to isolate the organism in large quantities from the interior of such smooth galls, and to demonstrate conclusively the infective migration of the bacteria from the original point of infection for very considerable distances through the plant. These secondary galls on Nicotiana will, therefore, now be described.

Cut surfaces of the internodes of the young flowering shoots of Nicotiana were inoculated in a manner similar to that described for Chrysanthemum. As in the latter plant, in some cases, a large rough gall arose on the end of the inoculated shoot and, as before, the bacteria were found to be present in very great numbers on the rough outer surface of the gall. More frequently in Nicotiana, however, the primary gall arising on the end of the shoot is much smaller; in such cases it is invariably found that a number of smooth galls arise as a series of swellings which extend to a considerable distance below the inoculated surface. Pl. VI, Fig. I6, shows such a series of smooth secondary galls on Nicotiana, and it will be seen that these are identical in appearance with similar galls on Nicotiana figured by Smith $(29$, Fig. 24, $x)$. Pl. VI, Fig. I6, is quite typical of a large number of inoculated shoots which we have obtained showing secondary galls. We successfully isolated Bacterium tumefaciens from the secondary gall (s.g. I) most remote from the inoculated surface and we have also stained these bacteria in situ within the galls. P1. VI, Fig. I7, shows a transverse section of the shoot seen in P1. VI, Fig. 16, through the swelling (s.g. 2) immediatelyabove (s.g. I). In this case there are four centres of disturbance in the cortex giving rise to three secondary galls and a tumour-strand. Serial sections at different levels of the shoot seen in Pl. VI, Fig. I6, have demonstrated the longitudinal continuity, throughout the length of the stem shown, of the tumour-strand and secondary galls seen in the cross-section in P1. VI, Fig. I7. Around the protoxylem of some of the bundles there are also small disturbances obviously resulting from the presence of the bacteria in these vessels. Pl. VI, Fig. I8, which is taken from the inner face of the vascular ring (at $p x$.) of the section seen in Pl. VI, Fig. I7, shows one of these small tumour-strands. Pl. VI, 
Fig. I9, shows tumour-strands in the pith of another similarly inoculated shoot of Nicotiana. Here the bacteria in intercellular cavities marked i.s. I, i.s. 2, i.s. 3 are forming a centre from which the stimulating influence is radiating outwards. In these cases it is again clear that there is no true intrusive growth of tumour-tissue : the stimulus merely results in the subdivision of the preexisting cells of the pith. This is seen even more clearly in Pl. VI, Fig. 20, which also shows the deeply-staining mass of $B$.tumefaciens in the intercellular space which forms the centre for the production of the gall. This figure also indicates that the invaded cavity may be slightly enlarged by the occasional necrosis of cells bounding it, but there are never, in our experience of crown gall, the marked necrosis cavities described for the Olive-knot disease due to Bacterium savastoni, Smith. This difference between the two diseases, however, would seem to be one of degree rather than of kind.

We have traced, in serial longitudinal sections, the passage of the bacteria along the very large intercellular spaces which are present in the stem of the Nicotiana affinis. Pl. VI, Fig. 2I, shows a longitudinal section of a part of a shoot at some distance below the surface which was inoculated eighteen days previously. The dark centres (i.s.) in the cortex are clearly seen, with tumour-tissue arising by the subdivision of cells on either side of the bacterial strand. Pl. VI, Fig. 22, shows, more highly magnified, the zoogloeal strand of $B$. tumefaciens seen advancing through a large, longitudinal, intercellular space in the pith of Nicotiana. Such zoogloeal strands of the bacteria, which are readily demonstrated by staining, are invariably found in sections of young secondary tumours on Nicotiana affinis, and, since detecting them in this plant, we have frequently observed them also in the Chrysanthemum. In the latter plant, however, the intercellular spaces are much smaller and less abundant, and we have not observed the zoogloea to penetrate to a depth greater than two millimetres from the cut surface of the shoot.

In addition to the definite zoogloea of $B$. tumefaciens which have thus been repeatedly observed in the intercellular spaces of both plants studied, it has been mentioned that the bacteria also enter the protoxylem elements of both infected shoots and leaves, and, travelling in these vessels, and also passively carried in them by growth extension, serve as centres for the development of secondary tumours. The secondary galls which we have described and figured (Pls. V and VI, Figs. II, I2, I3) for Chrysanthemum frutescens are of this type. They owe their origin and characteristics to the fact that they were derived by the inoculation of the basal region of leafrudiments at such an age that the first differentiation of protozylem of the leaf-trace had taken place, but the basal growth of the leaf-rudiment had not ceased. Pl. V, Fig. 4, shows a longitudinal section of an apex of Chrysanthemum frutescens, and the leaf $(l$.$) shows the stage in development at the time$ of inoculation for results such as are seen in PI. VI, Fig. I 2, to be produced. 
At this stage there is a single protoxylem element extending down from the base of the leaf into the shoot, towards its rudimentary vascular cylinder. Secondary tumours arise when the needle-prick introduces the bacteria into this protoxylem element either in the leaf-base or in the stem. If the rudimentary leaves infected are somewhat farther advanced, the needle penetrates the region at the extreme base of the leaf where growth has almost ceased, the organisms are not carried forward in the stretching protoxylem, and, instead of an elongated series of galls, a single large gall arises at the base of each leaf wounded and inoculated. PI. V, Fig. Io, illustrates this effect. If, on the other hand, the leaf-rudiment is very young, the gall which arises involves the whole rudiment and thus obliterates the leaf. In other cases, where the protoxylem is entered by the bacteria, the young leaf may be so severely wounded that the development of secondary galls is accompanied by a partial arrest of the leaf as in P1. VI, Fig. I3. The facts thus briefly summarized for the inoculations of leaf-rudiments of Chrysanthemum frutescens were obtained by the examination of serial sections of a large number of apices at differing periods varying from three to fifteen days after inoculation by transverse or longitudinal needle-pricks. The observations were controlled in the case of each apex examined by serial sections of a corresponding wounded but uninoculated apex of the same age. The results have shown that the secondary galls on the leaves of Chrysanthemum frutescens are largely accounted for by the bacteria inoculated into the young protoxylem, being carried by the stretching growth of this to some distance from the point of inoculation; our results on tobacco have shown that an actual migration of the bacteria is also possible in the protoxylem. The fact that the bacteria are restricted to the protoxylem in the secondary galls on the Chrysanthemum and that, though staining clearly shows them to be present, they are never so abundant as in the galls on the tobacco, fits with the undoubted difficulty which both Smith and ourselves have had in isolating the organism from these secondary galls on the Chrysanthemum. It would seem that there is, in these cases, little actual multiplication of the organisms after inoculation, while the undoubted very active migration and growth of zoogloeal strands in the shoot of tobacco clearly indicates the reverse. This may be correlated with the much greater ventilation of the tobacco shoot, its larger intercellular spaces affording more favourable conditions for the active multiplication of the highly aerobic Bacterium tumefaciens.

It may be mentioned here that measurements of the stem of the tobacco after inoculating the cut surface show that there is very little elongation of the stem such as occurs subsequent to the wounding of an apex either of Chrysanthemum or of the tobacco. In the secondary galls which arise below the inoculated stem-surfaces in the tobacco there is, therefore, no question of growth elongation playing any considerable part in the form and arrangement of the galls. 
Secondary galls and tumour-strands essentially similar in all respects to those we have described and figured for Chrysanthemum frutescens have, however, also been obtained on the leaves of Nicotiana affinis. Numerous needle-prick inoculations of the apices of young flowering shoots of this species of tobacco were made and results similar to those described by Smith have been obtained; but wherever the galls have a rough exterior the organisms are present in abundance on this surface, and when completely smooth galls occur they, like the secondary galls we have described above, have the organisms present in the intercellular spaces and vessels within. For such inoculations, both the enormous stretching by growth of the inoculated meristem and the actual migration and multiplication of $B$. tumefaciens within the vessels and cavities of the stem must be taken into account in explaining the resulting secondary galls and tumour-strands. In the tobacco, as Smith has shown, these frequently burst out to the exterior either from the pith or cortex, and the rough surface, which they then acquire, is richly populated with $B$. tumefaciens.

We have obtained no evidence of the migration of strands of tumourtissue to any distance at all comparable with that postulated by Smith, but we have shown earlier in this paper that the effect of the bacterial stimulus proceeding from definite centres invariably results in the subdivision and enlargement of cells. There is no intrusive growth of these dividing cells in Smith's sense, although there is often a slight displacement of the dividing cells due to the inequality of pressures developed by the abnormal celldivisions and enlargements. Pl, VI, Fig. 23, $d$, from the edge of one of the secondary tumours seen in Pl. VI, Figs. 16 and 17 , shows one of the most extreme cases of cell-displacement which we observed. Even in this case, however, at $e$ it is obvious that the tumour-cells are arising by subdivision of ordinary cortical cells. On the other hand, as we have already pointed out, Pl. VI, Figs. I9, 20, 2I, make it clear that the tumour-strands are in no real sense intrusive growths of tissue, but the result of intruding masses of bacteria forming centres of disturbance.

\section{Discussion OF RESUlts.}

The results of our work do not require extended discussion, but the more general bearings of the new facts we have established must be briefly considered. The study of the mode of occurrence and of the distribution of the bacteria in the galls is a necessary preliminary to the understanding of the manner of growth and development of the latter. Much of the work described in this paper is therefore concerned with obtaining exact knowledge regarding the position of the bacteria.

The demonstration of the bacteria, in large quantities, on the exterior of naturally occurring galls, and also upon those produced in the immediate neighbourhood of inoculation wounds, has explained the earlier difficulties of 


\section{I 8 Robinson and Walkden.-A Critical Study of Crown Gall.}

ourselves and others in isolating Bacterium tumefaciens from the interior of sterilized galls. This distribution of the bacteria also throws light on the form of these galls and their general resemblance to ordinary growths of callus such as occur on the twigs of trees. The organisms present over the hemispherical outer surface of the gall provide the continued stimulus which accounts for the fairly uniform meristematic activity in a region of the gall comparatively close to the surface. This continuity of stimulus explains the differences in the degree of reaction obtained in the galls and in ordinary growths of callus.

The presence of $B$. tumefaciens on the exterior of the galls also explains the extreme ease with which the soil in which diseased plants are growing becomes highly infectious, since the organisms must be washed into the soil whenever water falls on the plants.

The bacteria often associated as zoogloea-like strands have, on the other hand, been traced for shorter or longer distances from the point of inoculation. The course of this bacterial extension is by way of intercellular spaces and protoxylem. The recognition that the formation of tumourstrands and secondary galls follows along the track of invading bacteria leads to a reconsideration of some of the more specific comparisons that have been made between crown gall and malignant tumours.

Smith has held that the intrusive growth of tumour-tissue, which he has described for tumour-strands, is directly comparable to the migratory growth of the diseased tissues in certain forms of malignant disease. We have been unable to find any real intrusive growth in crown gall, but the demonstration of the bacteria advancing in the intercellular spaces and protoxylem fully explains the development of tumour-tissue in the neighbourhood of their path, and also the existence of strands of such tissue connecting secondary with primary galls and the threading of successive secondary galls in a linear series. In our experience the careful examination, by staining methods, of serial microtome sections usually reveals the relatively close proximity of the causal bacteria to the proliferating tissues. There is, therefore, no necessity to assume the stimulation of cells at any considerable distance from the active bacteria. It is unnecessary also to adopt Jensen's hypothesis that stimulated cells removed from the bacterial influence behave in a parasitic manner, as, according to him, do the cancer cells in the animal disease.

It was mentioned in the introduction to this paper that Smith has utilized the appearance of a radial stem-like structure in secondary galls on the leaves of Chrysanthemum for pressing even more closely a further comparison with cancer. He suggests that the stem-like structure occurs in the leaf because the tissues originally inoculated were those of the stem, and the comparison is directly made with those secondary malignant tumours which reproduce in distant organs the tissues of the organ originally diseased. 
This idea was originally suggested in relation to the conception that the secondary tumour in the leaf originated from an 'invading destructive growth' (Smith, 23, p. I6) derived from the stem. We have shown that the radial stem-like growth referred to arises by the active division of leaftissues on the adaxial side of the vascular bundles in relation to bacteria situated in the protoxylem. There can be no question of simply explaining the transformation of leaf-tissues into those of a 'pseudo-stem' by the fact that the original inoculation was made into the stem.

The appearances in question are in some respects similar to those described by Winkler (36) for the petiolar bundles on Torenia when adventitious buds arise on the lamina of the leaf. Here the remains of the desmogen of the leaf-traces give rise to an almost radial bundle by secondary thickening. In crown gall an exactly similar stimulation to this latter almost invariably occurs in the petiole or midrib of the leaf of Chrysanthemum frutescens below the position of the primary gall on the leaf. This, like the anatomical change in the petiolar bundle of Torenia, seems to be a correlation effect. The facts regarding such structural changes, while of great interest in themselves, do not, in our opinion, support any detailed comparison of the radial structure of secondary galls with the histological results of the active transference of tissues by infiltration or metastasis in malignant tumours.

The origin of leafy or bud-like growths on crown galls apart from preformed buds does not, in our view, afford any support to comparisons with malignant tumours. The new growths in plants can only in a very general way be regarded as equivalent to animal teratomas. Where such structures appear in crown gall they are comparable with the adventitious buds or roots that occur in ordinary cases of woody callus, or with the buds that arise very commonly on the cut surfaces of internodes of shoots or on mutilated leaves of Solanum lycopersicum, apart altogether from any infection by organisms. Smith's later work has afforded new and excellent examples of this phenomenon. This aspect of the question, however, lies outside the scope of this paper.

The most striking growths of crown gall are always obtained when regions of the plant which are capable of considerable further growth are inoculated. When, as in most of our experiments, the inoculations are made into immature organs the subsequent development of these in the control plant has to be taken into account in dealing with the causation of the effects obtained in the inoculated plant. The changes followed in the normal development of organs behind a growing-point are usually in themselves difficult to understand, but this only makes it the more necessary to consider the effects of the bacterial stimulation in the light of the potentiality for development of these organs. We have found, for example, in the present work that the very different effects produced by the inoculation of 
internodes of the stem of Nicotiana affinis and of the apex of Chrysanthemum frutescens are in greater or less part due to the different potentialities of development and growth in the two cases. In the internodes of tobacco practically no growth in length took place after preparing the surfaces for inoculation, while in the Chrysanthemum the immature leaves and stem of the inoculated bud continued their growth and development, although this took place under the influence of modifications introduced by the presence of the bacteria. We have thus throughout our work found it necessary and instructive to consider the resulting growths in the light of the subsequent development of the host plant after inoculation, and it has been seen that this development plays an important part in determining the form and distribution of the structures which arise. This continued development of plants, as contrasted with animals, must be borne in mind when comparisons such as we have been considering are instituted, and our results show that for this reason alone superficially similar structures, in the two cases, may have quite different methods of origin.

Whilst thus compelled by the facts we have described for crown gall to dissent from the close comparisons with cancer referred to above, we would, nevertheless, agree that there are features in the plant disease which suggest more general comparisons with malignant disease. In both cases, for example, cells and tissues are stimulated to active atypical proliferation, and it is possible that a real insight into the nature of the changes taking place under the influence of Bacterium tumefaciens might throw light on the changes taking place as a result of unknown causes in the cells of the animal tumours. We have as yet few facts relating to such features of crown gall, but we regard the cell-wall changes referred to in the body of our paper, and certain precipitation effects we have observed in the gall-tissues, as indicating the direction of further study in this connexion. Similarly we have made some preliminary steps in the investigation of the metabolic changes and the respiratory activity of the plant cells under the influence of $B$.tumefaciens, and we are not without hope that future investigation of the sequence of changes resulting from the activity of this organism upon the tissues of higher plants will throw light upon little-understood problems of tissue differentiation and of development in the healthy plant.

\section{SUMMARY.}

I. The development of the galls produced by the inoculation of cut surfaces of Chrysanthemum frutescens with $B$. tumefaciens has been traced from the earliest stages.

The effect of the bacterial stimulus is to produce a growth very similar in form, structure, and general appearance to callus growths on woody shoots arising as a result of wounding. At first the bacteria are located on 
the wounded surface, and to some extent also in the vessels, and in intercellular spaces of the cortex near to this. The later development of the gall is, for the most part, due to the active presence and multiplication of $B$. tumefaciens on the rough external surface of the gall.

2. Most of the work of Erwin F. Smith regarding the production of secondary tumours has been repeated, but additional results have been obtained which show that the facts bear very different interpretations from those adopted by Smith. Both in Chrysanthemum frutescens and in Nicotiana affinis we have definitely demonstrated, by staining, zoogloeal strands of $B$. tumefaciens intruding along intercellular spaces and protoxylem vessels forming centres for pathological disturbance and gall-production along the tract. This migration of the causal bacteria in experimentally inoculated shoots of Nicotiana affinis, in which little growth extension was possible, fully accounted for the secondary galls obtained. On Chrysanthemum frutescens secondary galls have only been produced by inoculating the meristematic tissues near the apices of shoots. In these cases, and also in the galls resulting from the inoculation of the growingpoint of Nicotiana affinis, the part played by the growth and extension of the wounded and inoculated tissues has been shown to be a very important additional factor in determining the form and distribution of the galls which arise.

3. The primary and secondary galls and tumour-strands arise by a subdivision and subsequent proliferation of pre-existing cells of the host plant in the presence of the bacterial stimulus. There is no invasive growth of tumour-tissue over any considerable distance. The intrusive growth of the bacteria in the intercellular spaces and in protoxylem vessels, together with growth extension of inoculated tissues, fully account for the strands of tumour-tissue connecting the secondary galls with those arising at the points of inoculation.

4. It is held that the results obtained regarding the distribution of the bacteria in the galls invalidate most of the close comparisons which have previously been made between crown gall and malignant tumours.

Barker Cryptogamic Research Laboratory,

UNIVERSity OF MANCHESTER. 


\section{LITERATURE CITED.}

1. Blumenthal, F., and Hirschfield, H.: Untersuch. über bösartige Geschwülste bei Pflanzen und ihre Erreger. Zeitsch. f. Krebsforschung, xvi. 5I, I9I 7 .

2. Cavara, - : Tuberculosis of Vine. Staz. sperim. agrar. ital. Modena, xxx. 483, I897.

3. Friedemann, U., and Magnus, W.: Das Vorkommen von Pflanzentumoren erzeugenden Bacterien im kranken Menschen. Ber. der deutsch. Bot. Ges., xxxiii. 96, I9 I 5.

4. Friedemann, U., Bendix, Hassel, and Magnus, W. : Der Pflanzenkrebserreger (B. tumefaciens) als Erreger menschlicher Krankheiten. Zeitsch. für Hygiene, lxxx. I 29, I9I 5.

5. Friedemann, U. : Weitere Mitteilungen über das B. tumefaciens. Ibid., lxxxiv. 249, I9I7.

6. HaRvey, R. B. : Relation of Catalase, Oxidase, and $\mathrm{H}^{+}$-Concentration to the Formation of Overgrowths. Amer. Journ. Botany, vii. 2 I I, 1920.

7. Hedgecock, George: Hairy Root Disease of the Apple. U.S. Dept. Agric. Bull., xc. I5, I906.

8. : Cross Inoculation of Fruit Trees and Shrubs with Crown Gall. Ibid., cxxxi. 2 I, I908.

9. Jensen, C. O.: Von echten Geschwiilsten bei Pflanzen (Deuxième Conf. internat. pour l'étude du cancer, Paris, I910). Med. Kgl. Vet. Land. Copenhagen, Serum Lab., vii, I9Io.

10. - Undersøgelser vedrørende nogle svulstlignende Dannelser hos Planter. Kgl. Veterinær og Landlohøjskoles Aarssk. Copenhagen, Serum Lab., No. 54, I9r8.

11. KÜster, E. : Pathologische Pflanzenanatomie, p. 263 . Jena, 1916.

12. Lang, W. H.: Some Aspects of Vegetable Pathology in Relation to Human Disease. Brit. Med. Journ., 1922 , ii. $95^{8}$.

13. Levine, M. : Studies on Plant Cancers. I. The Mechanism of the Formation of the Leafy Crown Gall. Bull. Torrey Bot. Club, xlvi, 447, 1919. (Abstr. in Expt. Stat. Rec., xliii, No. 3 , p. 242,1920 .)

14. : Studies on Plant Cancers. II. The Behaviour of Crown Gall on Ficus elastica. Mycologia, xiii. I, I 92 I.

15. : Studies on Plant Cancers. III. The Nature of the Soil as a Determining Factor in the Health of Beta vulgaris and its Relation to the Size and Weight of the Crown Gall produced by Inoculation with Bacterium tumefaciens. Amer. Journ. Bot., viii. $5 \circ 7$, I $92 \mathrm{I}$.

16. Magnus, W.: Wund-callus und Bakterien-Tumore. Ber. der deutsch. Bot. Ges., xxxvi. 20, 1918.

17. Peklo, - : Ueber die Smith'schen Rübentumoren. Zeitsch. für Zuckerindustrie in Böhmen, xxxix. 204, I9I5.

18. Riker, A. J. : Studies of Crown Gall. Abstracts of papers presented at meeting of American Phytopath. Soc., Toronto, Dec. I 921 . Abst. in Phytopathology, xii. 55, 1922.

19. Smith, Erwin F., and Townsend, C. O.: A Plant Tumour of Bacterial Origin. Science, N.S., xxv. 671, 1907 .

20. Smith, Erwin F., Brown, N. A., and Townsend, C. O. : Crown Gall in Plants, its Cause and Remedy. U.S. Dept. Agric. Bull., ccxiii, IgII.

21. Smith, Erwin F.: Etiology of Crown Gall on Sugar Beet. Phytopathology, ii. 270 , I 9 I 2.

22. - Le cancer est-il une maladie du règne végétal ? Proc. Congr. Internat. Path. Comp. Paris, tome ii, I9I2.

23. Smith, Erwin F., Brown, N. A., and McCulloch, L.: The Structure and Development of Crown Gall. U.S. Dept. Agric. Bull., cclv, I9I 2.

24. Smith, Erwin F.: Cancer in Plants. Proc. I 7 th Internat. Congr. of Medicine, London, Sect. III, Aug. I9I3.

25 .

26. : Bacteria in Relation to Plant Diseases, vol. ii, I9II. Journ. Cancer Researeh, i. 23 I, I916. 


\section{Robinson and Walkden.-A Critical Study of Crown Gall.}

27. Smith, Erwin F.: Further Evidence that Crown Gall of Plants is Cancer. Science, N.S., June 23 , I916.

28. : Mechanism of Tumour Growth in Crown Gall. Journ. Agric. Research, iii. $16_{5}$, I 917.

29. : Embryomas in Plants (produced by Bacterial Inoculations). Johns Hopkins Hospital Bull., xxviii. 277 , 191 7 .

30. : The Relations of Crown Gall to other Overgrowths in Plants. Mem. Brooklyn Bot. Garden, i. 448, I918.

31. : An Introduction to Bacterial Diseases of Plants. Philadelphia and London, I920.

32. - Effect of Crown Gall Inoculations on Bryophyllum. Journ. Agric. Research, xxi. 593 , I $92 \mathrm{I}$.

33. Swingle, D. B., and Morris, H. E. : Crown Gall Injury in the Orchard. Agric. Expt. Sta. Bozeman, Montana, Bull., cxxi, I9i8.

34. Toumey, J. W.: An Enquiry into the Cause and Nature of Crown Gall. Agric. Expt. Sta. Arizona, Bull., xxxiii, I900.

35. Walkden, H.: The Isolation of the Organism causing Crown Gall on Chrysanthemum frutescens in Britain. Ann. Bot., xxxv. $137,1921$.

36. Winkler, H. : Ueber die Umwandlung des Blattstieles zum Stengel. Pringsheim's Jahrb. f. wiss. Bot., xlv. I, 1908.

\section{EXPLANATION OF FIGURES IN PLATES V AND VI.}

Illustrating Messrs. Robinson and Walkden's paper on a Critical Study of Crown Gall.

PLATE V.

Fig. I. Typical crown galls produced on Chrysanthemum frutescens by inoculating cut surfaces of the stems with $B$. tumefaciens. $a$ and $b$ are galls four months old ; $c$ is a younger gall produced by inoculating an axillary shoot which arose near to the first gall $(a)$. Natural size.

Fig. 2. Radial longitudinal section of a gall (four months old) on the cut surface of a stem. The callus-like growth is shown, and also the extension of the influence leading to an abnormal increase in diameter of the stem below the gall. $\times 5$.

Fig. 3. Radial longitudinal section of a similar gall to that in Fig. 2, five and a half months old. $a$, woody gall-tissue; $b$, actively proliferating gall-tissue; $c$, layers of necrosed cells. $\times \mathrm{I} \frac{1}{2}$.

Fig. 4. Median longitudinal section through the apex of a shoot of Chrysanthemum frutescens, showing leaf-rudiments and parts of young leaves of various ages. The leaf $(l$.$) has just differentiated$ the first protoxylem element of the leaf-trace and is at the stage of development usual when inoculations result in secondary galls on the leaf similar to those seen in Fig. I 2, s.g. I, s.g. 2, s.g. $3 . \quad \times 5$ o.

Fig. 5. Portion of transverse section of young stem of Chrysanthemum frutescens at the level of the first distinctly visible internode below the growing-point of the shoot. $\times 75$.

Fig. 6. Film of Bacterium tumefaciens stained with carbol fuchsin. $\quad$ x I 250.

Fig. 7. Radial longitudinal section of stem of $C$. frutescens, showing the cut surface nine days after inoculation. The dark staining of some areas and of cell-walls near the surface is due to bacteria in the protoxylem vessels $\left(p x_{\text {. }}\right)$, pericycle fibres $(\not f$.$) , and in some intercellular spaces (i . s$.$) .$ $\times 75$.

Fig. 8. Radial longitudinal section of stem similar to that seen in Fig. 7, fifteen days after inoculation. Shows the region of the pith adjoining the vascular bundle and the progression of the disturbance outwards from the bundles across the pith. Elongated cells $(t r$.) with tracheide-like thickenings are appearing. $\times 6_{5}$.

Fig. 9. Radial longitudinal section of stem similar to Figs. 7 and 8, fifteen days after inoculation. Bacteria present in protoxylem $(p x$. $)$ and in a line of intercellular spaces (i.s.) in the cortex. This line of infection, which is the dark region immediately to the left of the large-celled cortical tissue in the photograph, forms a centre for pathological disturbance. $\times 5^{\circ}$. 


\section{Robinson and Walkden.-A Critical Siudy of Crown Gall.}

Fig. I0. Portion of a shoot of Chrysanthemum frutescens five weeks after the inoculation of the apex by a single transverse needle-prick. Six galls at the bases of leaves separated by one or more internodes are seen. The whole of the extension of the shoot above the lowest gall $(g \cdot)$ has taken place subsequent to inoculation. Natural size.

Fig. II. Portion of shoot of Chrysanthemum frutescens, showing primary gall (p.g.) with rough exterior produced on the stem by needle-prick inoculation. At s.g. is a smooth secondary gall on the petiole of the leaf. Natural size.

\section{PLATE VI.}

Fig. I2. Portion of shoot of Chrysanthemum frutescens inoculated by a single longitudinal needle-prick at apex. Large primary gall $(p . g$.$) with rough exterior on stem; smooth secondary$ galls (s.g. I, s.g. 2, and s.g. 3 ) extending along midrib of leaf. Natural size.

Fig. 13. Portion of shoot of Chrysanthemum frutescens inoculated by single transverse needleprick at apex. Large primary gall $(p \cdot g \cdot)$ on stem, and on deformed leaf above this an elongated secondary gall (s.g.). Natural size.

Fig. I 4. Radial longitudinal section of the smonth secondary gall $(s . g .2)$ in Fig. 12 . The tissues on the adaxial side of the protoxylem $\left(p x_{.}\right)$are subdividing, especially in the immediate vicinity of this. No marked intrusive growth. $\times 15$.

Fig. I5. Transverse section of secondary gall $(s . g$.$) on deformed leaf seen in Fig. I3. Tissues of$ midrib modified to give a radial structure. Bacterium tumefaciens was present in the protoxylem region at the centre of this modified midrib. $\times \mathrm{I}_{5}$.

Fig. 16. Portion of stem of Nicotiana affinis, showing small primary gall $(p . g$.$) at the upper end,$ produced by inoculation of the cut surface; a linear series of smooth secondary galls is seen extending for some distance below the inoculated surface. B. tumefaciens isolated from s.g. I. About five weeks old. Natural size.

Fig. I7. Transverse section of the stem in the region of the secondary gall (s.g. 2) seen in Fig. I6. Three incipient secondary galls (s.g. I, s.g. $2, s . g .3)$ and also a tumour strand $(t . s$.$) are seen in the$ cortex. At $r$ a root-rudiment is visible. $\times \mathrm{I} 2$.

Fig. I8. Portion of the xylem and pith of the section seen in Fig. I7. At $p x$. the protoxylem. elements are filled with bacteria, and the surrounding cells have begun to subdivide to give rise to a small tumour-strand. $\times 6_{5}$.

Fig. 19. Transverse section of similarly inoculated shoot of Nicotiana affinis to that seen in Figs. 16 and 17. Three tumour-strands are present in the pith, each having arisen around a centre of bacteria situated in intercellular spaces (i.s. I, i.s. 2, i.s. 3). $\times 65$.

Fig. 20. Transverse section of similar tumour-strand to those shown in Fig. I9. B. tumefa. ciens present in the large intercellular space (i.s.) which forms the centre for the outward radiation of the disturbing influence leading to subdivision of cells. $\quad \times 270$.

Fig. 21. Radial longitudinal section through part of inoculated stem of Nicotiana affinis similar to that shown in Fig. I6. The deeply-stained intercellular spaces (i.s.) containing bacteria are shown in the cortex with tumour-tissue arising by subdivision of cells on either side of the bacterial strand. The cut surface was situated a considerable distance above the portion figured. $\times 50$.

Fig. 22. Portion of the pith of Nicotiana affinis in longitudinal section. Zoogloea-like thread (z.) of $B$. tumefaciens advancing in the large intercellnlar space. $\times 550$.

Fig. 23. Portion of the marginal region of one of the incipient secondary galls seen in Fig. 17 . At $d$ tumour-cells appear to be intruding between the normal cortical cells, but at $e$ the tumour-cells are seen to be arising by subdivision of cortical cells. $\times 150$. 

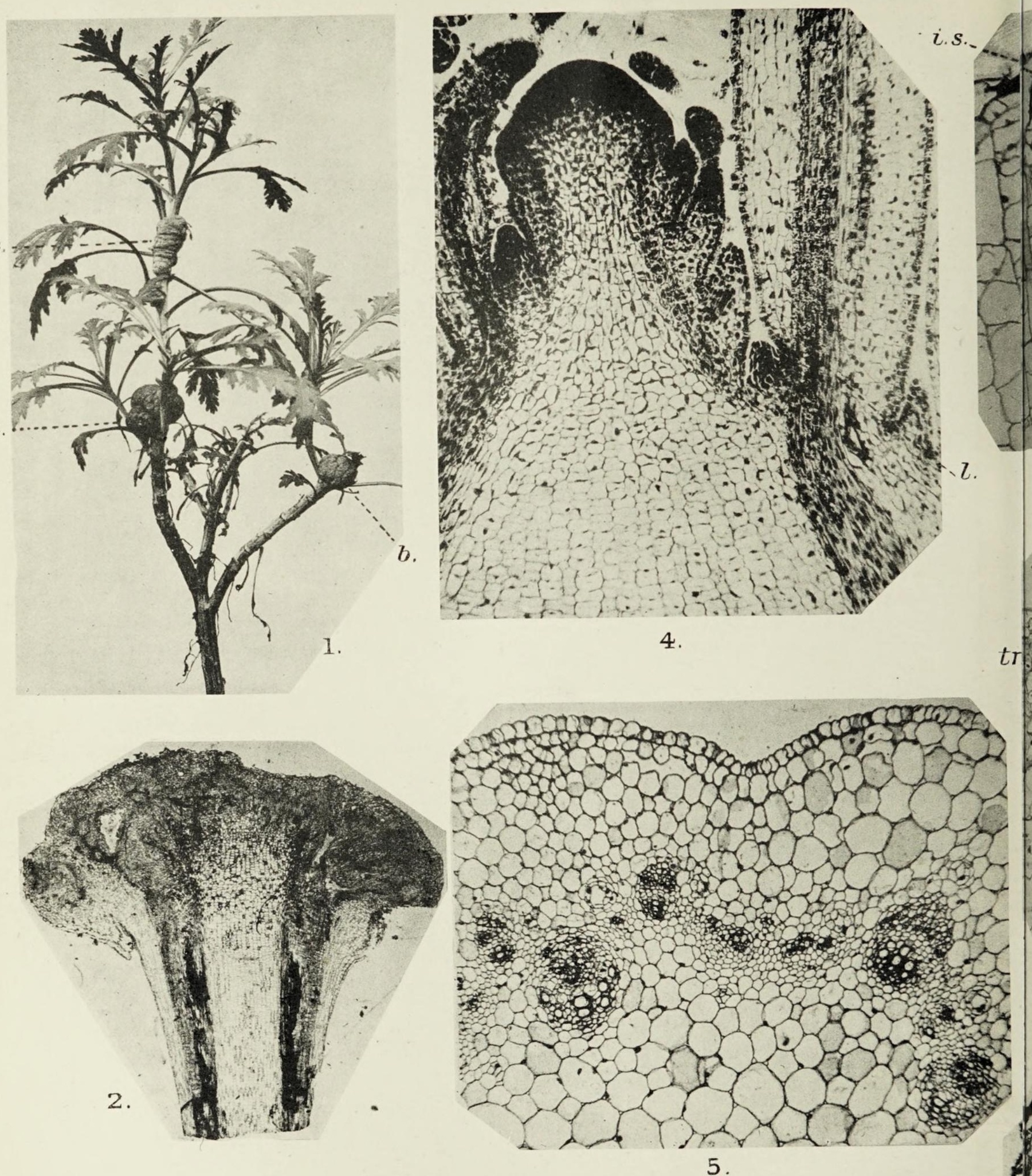

c.
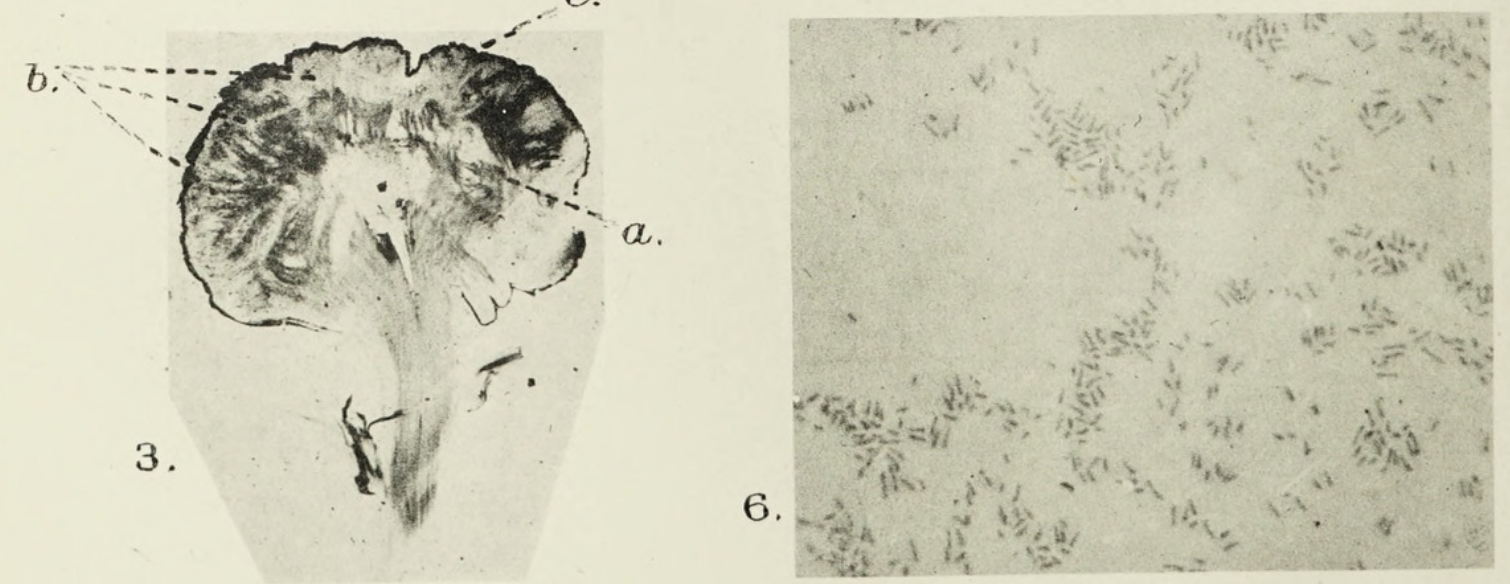

Annals of Botany,

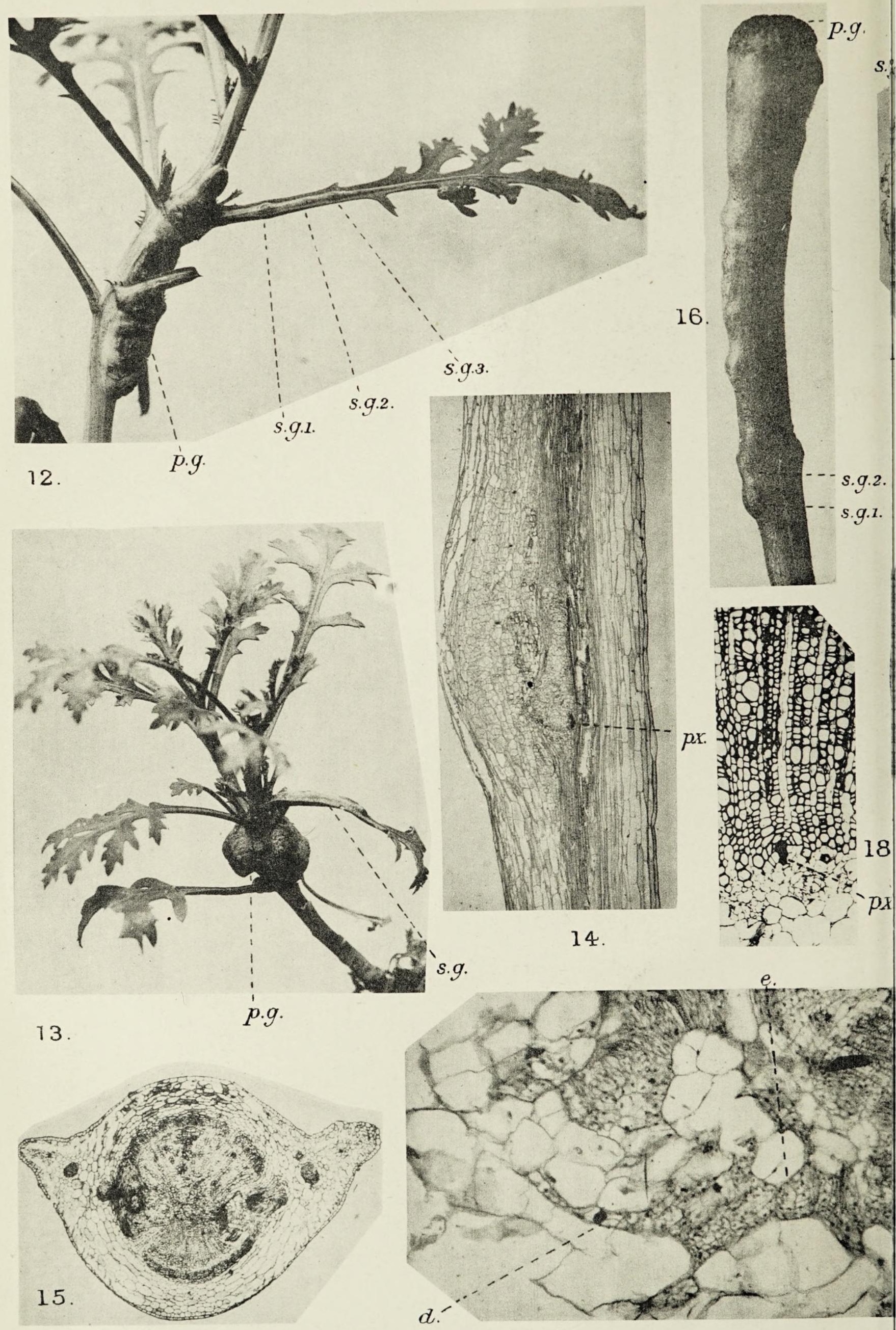

ROBINSON \& WALKDEN-CROWN GALL. 


\section{$2 \mathrm{BHL}$ Biodiversity Heritage Library}

Robinson, Wilfrid. and Walkden, H. H. 1923. "A critical study of crown gall." Annals of botany 37, 299-324.

https://doi.org/10.1093/oxfordjournals.aob.a089847.

View This Item Online: https://www.biodiversitylibrary.org/item/270686

DOI: https://doi.org/10.1093/oxfordjournals.aob.a089847

Permalink: https://www.biodiversitylibrary.org/partpdf/319084

\section{Holding Institution}

New York Botanical Garden, LuEsther T. Mertz Library

\section{Sponsored by}

BHL-SIL-FEDLINK

\section{Copyright \& Reuse}

Copyright Status: Public domain. The BHL considers that this work is no longer under copyright protection.

This document was created from content at the Biodiversity Heritage Library, the world's largest open access digital library for biodiversity literature and archives. Visit BHL at https://www.biodiversitylibrary.org. 